\title{
Sustainable Supply Chain of Enterprises: Value Analysis
}

\author{
Aneta Oniszczuk-Jastrząbek ${ }^{1}$, Ernest Czermański ${ }^{1}$ and Giuseppe T. Cirella ${ }^{2, *}$ (1) \\ 1 Institute of Maritime Transport and Seaborne Trade, Department of Global Economy, Faculty of Economics, \\ University of Gdansk, 81-824 Sopot, Poland; aneta.oniszczuk-jastrzabek@ug.edu.pl (A.O.-J.); \\ e.czermanski@gmail.com (E.C.) \\ 2 Department of Transport Economics, Faculty of Economics, University of Gdansk, 81-824 Sopot, Poland \\ * Correspondence: gt.cirella@ug.edu.pl
}

Received: 3 December 2019; Accepted: 3 January 2020; Published: 6 January 2020

\begin{abstract}
An enterprise carrying out operations according to the sustainable development (SD) concept should maximize its business goals without affecting interest groups. It requires not only a rethinking, but also a partial allocation of profit to social goals-used to contribute to and create a positive image of the enterprise and improve its competitiveness-over the long-term. Operations should result in an increase in profit—indirectly—by way of demand. This paper explores the sustainable supply chain (SSC) concept and the interplay of corporate social responsibility (CSR) within business objectives. The concept of SSC-compliant CSR is primarily stressed as an executive, top-down centric role. Businesses and societies at large that foster an SD continuum are considered healthy economies. The SD of enterprises and CSR in business are explored in relation to social investment and considered a viable long-term strategy for doing business. A pilot case study of Poland is carried out as a value analysis of the SSCs of enterprises. The key findings illustrate the benefits and problems of SSCs applied at the enterprise level. The problems of applying the principles of SSC within the enterprise and the connection between its levels of strategy and social value in terms of CSR and entrepreneurial operations are examined. Comparative studies indicate a number of overlapping trends in which positive SSC is cross-functional toward business partners, suppliers, customers, investors, and local communities.
\end{abstract}

Keywords: sustainable development; corporate social responsibility; interest groups; economic development; business goals; Poland

\section{Introduction}

The world's economy has greatly advanced over the past century [1]; nonetheless, technical progress and reactive, unsound exploitation of natural resources has led to intensified negative economic backlash. Economic concerns are intertwined with environmental pollution, increased unemployment, worsening standards of living, and persistent, continual marketing manipulation via consumer habits. As a result, the reduction of natural resources threatens supply chain efficiency-especially the transformative stages of natural resources, raw materials, and components used for the finalization of products [2,3]. The inept management of goods harvested from the environment can negatively steer suppliers away from properly providing the necessary goods that customers demand, as well as large-scale market share loss to associated enterprises [4,5]. Business objectives that expand beyond the sole need of generating profit find themselves defining corporate social responsibility (CSR) as part of their bottom line [6-8]. Over the last few decades, the concept of sustainable development (SD) has relished a period of increased attention, accompanied by changes in attitude and expectation from all levels of society. Elkington's [9-11] triple bottom line (TBL) framework interlinks environment, social, 
and economic spheres into performance standards that create greater business values. Businesses and society at large foster this SD continuum; enterprises operate in such a manner that the application of SD-oriented rules—coupled with sound and achievable profit margins—can equate with a successful business strategy. Fittingly, executives face a string of challenges throughout the supply chain by jostling for SD-compliant suppliers that minimize non-renewable resources while, at the same time, limiting cost.

In contemporary economics, value-making chains increase by generating technical, organizational, social, and cultural innovations. The strategy of enterprise need is to take into account various group interests (i.e., from within the business) and consider their goals, responsibilities, and limitations. As a consequence, they develop via the maturation of socially acceptable CSR activity by creating, implementing, and monitoring such operations business-wide. This cause-and-effect development is expected, since conflict among particular parties may arise due to opposing expectations. In accordance with Kruk [12], the assumptions Elkington [9] formulates by way of the TBL are the crux in which equivalent spheres are equally impacted and balanced among one another. Overarching CSR-based activities directed at improving environmentally- and socially-related responsibility frame key elements in achieving a TBL equilibrium. Within enterprises, a number of practices-according to Albińska [13] and Borys and Sleszyński [14]—affect SD operations; however, any such practice should simultaneously take into account the needs of future generations as well as strive for environmental conservation, social ontological equality, and economic well-being [15]. Enterprises that focus on a TBL equilibrium should consider both internal and external associations. Internal associations point at how enterprise management functions (e.g., at the board level) while external associations refer to the relationship with the natural environment and actions toward business partners, suppliers, customers, investors, and local communities [16-18]. Aguilera et al. [19] list four levels of CSR-related actions (i.e., individual employees, organizational activities, national objectives, and global ambitions), in which each level can be further broken down into three distinct pro-CSR activities: Instrumental, relative, and moral. Hence, if CSR is properly implemented within an enterprise, proper ethical conduct at all levels of society should come into play (i.e., positive local integration, national acceptance, and global integrity). According to Gasiński and Pijanowski [20], a number of instrumental initiatives has been developed in successfully implementing SD within enterprises (Table 1).

The CSR of enterprises should include both operational activities of companies as well as strategic control of business practices. The concept should be fully implemented (i.e., it should be introduced throughout the entire structure of the enterprise) so that it supports all operations throughout the supply chain process [21]. This process, namely the sustainable supply chain (SSC) concept, is utilized as an important activity that can support enterprises in improving overall performance [22,23]. Within any CSR strategy, consideration should also reflect the enterprise's property concerns-including any socially responsible investments which could attest to its CSR management and operational soundness. Taking this into account, this paper explores the literature and relies on primary and secondary research techniques (i.e., interviews with entrepreneurs and qualitative evidence) to create a foundation for business-oriented SD and its value throughout the SSC process. With increased attention related to a greening of the SSC management process [24], as well as influencing factors that can contribute to sustainability performance enhancement [25], SD-compliant operations become the working norm. Environmental collaboration is a key relational capability that facilitates strategic formulation and execution of SSCs [22-24,26]. Research suggests (i.e., via TBL reporting) important collaborative linkages with suppliers that especially lack social dimensions [22,24-26]. Touboulic and Walker [27] piece together SSC management theories in a structured literature review, which formulates a contemporary understanding of the current state of the art, as well as future development objectives. They suggest that, in the SSC process, "theory-building efforts" [27] remain somewhat curbed and under-explored. Conceptualized characteristics of SSC frameworks should be mapped out and act as the first step and analytical focus for the future. As such, we report upon a number of leading enterprises in which pro-social actions are employed and undertake an examination of how 
one might increase the value of the SSC process, considering CSR advancement and implementation. A breakdown of the paper is structured as follows: Section 2 explores SD of enterprises and CSR in business, Section 3 comprises a case study, Section 4 elucidates a discussion on integrated management of SD in the supply chain, and Section 5 contains the conclusion.

Table 1. Instrumental initiatives for sustainable development (SD) of enterprises, adapted from Gasiński and Pijanowski [20].

\begin{tabular}{ll}
\hline Risk & Threat \\
\hline - $\begin{array}{l}\text { Cost reduction optimization leads to limited } \\
\text { resources and energy consumption rate in the } \\
\text { supply chain }\end{array}$ & $\begin{array}{l}\text { Necessitate the management of a large number } \\
\text { of interactions among interest groups (e.g., } \\
\text { employees, representatives of society, } \\
\text { and suppliers) which may require additional } \\
\text { motivation and resources }\end{array}$ \\
& \\
\end{tabular}

- Increasing involvement and creativity of employees as well as building a trustworthy image of employers and business partners
Low awareness of market participants' value of corporate social responsibility (CSR) within a triple bottom line (TBL) framework
- Development of environmental and social innovations - both directed at a product and its usefulness-as well as business model development enables distinction within the market and adjustment to dynamic changes in consumer needs
- Low purchasing power equity in which forced pricing becomes the primary reason for purchasing a service or product-not its manufacturing or enterprise value (i.e., regardless of any fair-trade-related concerns)
- Exchange of experience and trust among business partners enables faster identification and response time to market expectations
High susceptibility to enterprise loss in reputation or unethical operations of firms in the supply chain
- Increase the impact factor of economic conditions and strengthen the stability of the environment for adequate involvement in socially-oriented problems
Spread of news by competitors, trade unions, consumer organizations, etc. on cases of inadequate CSR regulation and risk of complaint or litigation

increase in expenditures (i.e., lower rates of return and sometimes a longer time needed to manufacture and distribute a product due to higher environmental and social standards)

\section{SD of Enterprises and CSR in Business}

Social investment should be considered a long-term as well as strategic objective. Such investment, once implemented, should focalize on solving social problems. Their aim is to create the basis for a balanced level of SD within society-often implemented by way of the partnership principle between public authorities and non-government organizations (NGOs) [28]. According to Porter and Kramer [29], there is a balanced co-existence in which enterprises require society and society requires enterprises. This vis-à-vis relationship in a healthy society can create demand if the enterprise offers value as well as the fulfillment of its own needs and targets within its niche-related market. Enterprises that only meet their goals at the expense of society will achieve subpar success [29]. Activities centered on socially-oriented marketing (e.g., honest promotion, setting prices, and taking care of product quality) also come into play, and are important since they project (i.e., to some degree) the mirror image of society itself. Marketing plays a key role in CSR strategic operations, since it is responsible for the enterprise's relationship with its interest groups and the enterprise's relationship with society 
at large [30]. Unfortunately, marketing is too often concentrated at the product level, neglecting social and operational results. The basis of marketing should be focused on customer needs with respect to profit $[31,32]$. It should be seen as a tool of SD in which responsibility is weighted on the identification, forecasting, and fulfillment of customer requirements, society, and interest groups' societal provision for a balanced co-existence. Being socially responsible, however, does not mean giving up basic tasks of the enterprise $[7,30]$. As such, there is growing social awareness that marketing designers are using to strategize enterprise operations within the scope of their interest groups without compromising profitability [33].

The goal of pro-social activity is to create value for interest groups that can be regarded as societally-accepted. Interest groups, satisfied with social activities of an enterprise, become loyal, emotionally-tied (i.e., over the long-term), and, subsequently, result in an increase in enterprise value $[6,34]$; it should be noted that enterprise owners constitute the last group of interest groups that will benefit from the created value $[7,35]$. Creating a higher value within society (e.g., for customers and employees) will manifest itself as a higher value for enterprise owners. This higher value directly relates to the strong motivational factors used to manage enterprise resources which promote healthy and vibrant competitiveness. Hillman and Keim [36] prove that when social operations are directly aimed at interest groups, it brings benefits not only to interested parties, but contributes to an increase in value for owners. Conversely, participation in social problems not connected with interest groups' expectations may negatively impact value for all parties, including owners [36]. Enterprises should identify interest groups which contribute the most to strategy implementation and have the strongest impact in increasing enterprise value [37,38]. The meaning of value for the owner is not univocal and is enterprise-specific (i.e., value may mean something totally different in terms of branch, size, level of development, organizational culture, and place and position) in a supply chain.

For an enterprise owner, value can be defined as the return of capital, organizational growth, achieving the position of market leader, profit, surviving a market crisis, growth potential, innovation, and human capital value. Employees, on the other hand, regard value in terms of better wages, relations with other employees and management, and skill development [39-41]. Creditors expect fulfillment and the obligation of timely investment (e.g., paying back loans and profits in the form of interest) to minimize risk and capital loss. Suppliers strive to develop stable cooperation, growth in orders, and timely delivery, while customers expect an increase in product satisfaction, quality, and price [42-44]. The level of customer satisfaction can be measured by the quality of a product compared to its price, as well as the services offered before, during, and after sales. Central and local authorities are interested in increasing tax flow, the participatory level of financing non-profit bodies (i.e., via the social environment of an enterprise), and actions towards charity institutions and the like $[45,46]$. The priorities of CSR, in terms of dialog, should incorporate an enterprise mission statement, strategic planning, and operational activities. The 26000 ISO normative recommends that decision structures and processes, as denoted by Gasiński and Pijanowski [20], should enable:

- Accounting employees to undertake obligations and managerial involvement of staff in SD-related matters,

- creating and cultivating a culture of social responsibility,

- creating a motivation system (i.e., based on financial and non-financial incentives) that promotes socially responsible attitudes,

- efficient utilization of financial, natural, and human resources,

- propagating equal opportunities for groups insufficiently represented at higher posts,

- achieving a compromise between the organization and interest groups,

- establishing bilateral communicative processes with interest groups,

- propagating participation of all levels of operations, directed within the sphere of social responsibility, 
- balancing levels of authorities, responsibilities, and a number of people making decisions on behalf of the enterprise,

- monitoring implementation and decisions in a socially adequate manner, and

- periodic verification and assessment of organization order, its modifications, and manifesting changes.

Figure 1 illustrates possible interest groups impacting an increase in enterprise value. As such, the implementation of CSR operations requires not only proper legal processes, but a competitive market niche in which interest groups can interplay in an enterprise's development [47-51]. By implementing socially responsible operations, an enterprise may build its competitive edge in such areas as ecology, employee participation, shareholder promotion, and social problem-solution awareness. In accordance with Windsor [52], economic and legal responsibility of a company is socially needed, while philanthropy is socially required.

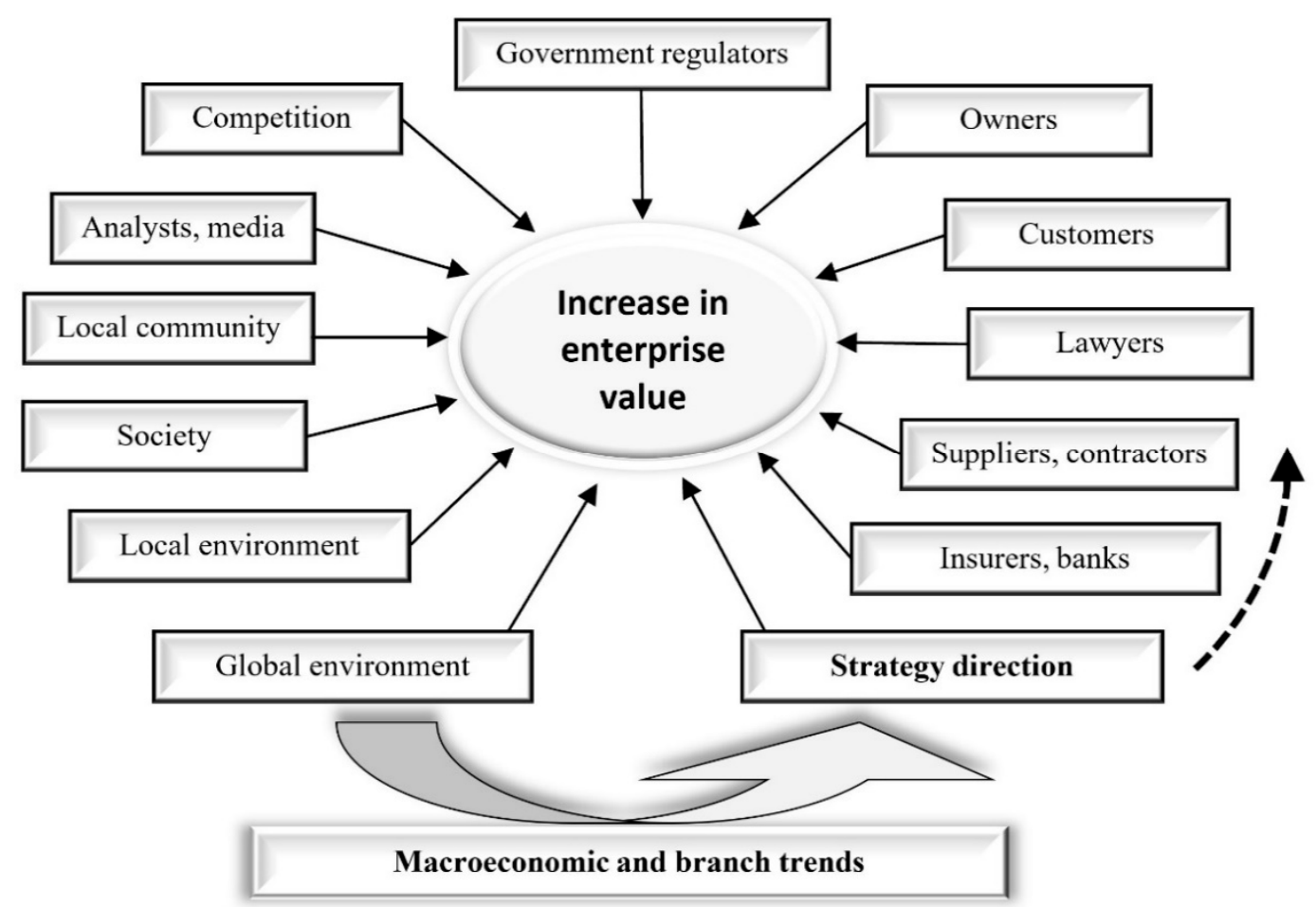

Figure 1. Interest groups impacting value growth of enterprises, adapted from Gasiński and Piekalski [53].

Opponents of CSR claim that many owners and managers alike reject CSR due to the fact that introducing such procedures is too costly, not only at the introductory level, but also during policy implementation that demands social goals and society-related program advancement. In reference to CSR costs, it not only repudiates the basic economic principle of cost minimization, but makes competing with other enterprises not undertaking such operations more difficult [31,44]. In contrast, supporters of CSR indicate that in the past few decades, many large American and European enterprises competing for technological advancement and organizational culture also compete for ethical and social attitude connected with organizational culture $[42,43,46]$. These developments indicate (i.e., often intentionally overlooked by CSR opponents) that ethical and social approaches can result in benefits that become one of the competitive elements in modern business structures (i.e., by not affecting market mechanisms but rather by supporting them) [47,49-51].

Another charge against the notion of CSR is that it requires moral obligation. However, for many economists and financiers, enterprises do not have moral obligation because the subject matter is not based on morality, but rather individual operations within an organization (i.e., determined sovereignly 
with individual responsibility). To this end, an enterprise differs from a human being in that it does not have a conscience (i.e., something conscienceless cannot be morally responsible) $[42,50,51,54]$. One has to remember, however, that an enterprise is still a team of people that are conscious (i.e., a sort of collective consciousness), in which counter-arguments have been debated and merit further examination $[37,49,50]$. In enterprise-related operations, fiscal decisions may be presented as functions of impersonal processes, in which decisions are a result of a number of individual factors making up a collective output (i.e., an individual decision by an employee is only a fraction in a large set of factors impacting a decision of the enterprise) [48-50,55]. Correspondingly, an executive managing an enterprise is said to represent the interests of the owner. Executives are, respectively, employed to make profit and not to engage in tasks that are outside this purview (e.g., nature and environmental protection or local community gains). The mission of maximizing long-term value for the owner [56], in the name of whom the executive operates, is the principal duty. A manager, besides representing interests of the owner, should remember citizenry duties and cannot overlook that operations undertaken in the name of an enterprise still have positive and negative consequences $[43,50,51,56]$. Finally, CSR has sometimes been said to be impossible to introduce (i.e., in practice), in that it is referred to as an advertising scheme (e.g., due to public relations and common fraudulent marketing examples in big business). Contrariwise, research suggests that a growing number of enterprises list pro-social activities, e.g., at the local level, as one of their principle mission statements [34]. It also suggests that CSR does not necessarily result in bankruptcy, and-in many cases-becomes an additional factor for success $[43,44,57]$. To better piece together the concept of SD of enterprises and CSR in business, a case study is presented. In retrospect of the varying pitfalls (i.e., from stakeholders), CSR in business requires additional accountability for environmental and social performance to create an SSC precedent. Such a precedent would include supply-chain integrity of "business and ethics [ ... ] led by improvements in SSC management practices" [23]. We examine various enterprises and explore and analyze the intricacy of CSR with emphasis on the SSC concept, and present a conceptual connection between an enterprise's level of SSC strategy and its social value.

\section{Case study}

\subsection{Methodology}

To better explore the foundation for business-oriented SD and its value throughout the supply-chain process, we examined the literature and utilized primary and secondary research techniques in a nationwide pilot case study of Poland. Interviews were held with entrepreneurs, in which qualitative evidence was collected to assist with the analysis and interpretation of the study. Moreover, we conducted a questionnaire across all business sectors of the country, dividing enterprises by size: (1) Micro-, small-, and medium-sized enterprises (SMEs) (i.e., from 1 to 250 employees) and (2) large enterprises (i.e., more than 250 employees). The sampling method used consisted of a simple random selection which equated to the same probability of selecting any of the enterprises within the pool. The sampling was divided according to the following criteria: Employment, net turnover, legal form, and location within each particular region. A total of 372 correctly completed questionnaires were completed. Characteristics of the enterprises, in terms of legal form, were broken down into seven major typologies: Major share of limited liability companies (41.7\%), stock companies $(29.0 \%)$, individuals engaged in business-like activities (15.3\%), individuals engaged in economic activity in the form of civil firms (5.6\%), general partnerships (4.2\%), and limited partnerships and co-operatives ( $2.8 \%$ and $1.4 \%$, respectively). The survey was conducted from 19 March to 2 April, 2019 on the website ebadania.pl, an online questionnaire system. The questionnaire consisted of eight questions, of which four related to the respondent's details while the latter four used a matrix table multi-choice attitude scale, i.e., integrating a Likert scale, in which all items were assigned intensity (i.e., interval measuring) scales $[58,59]$. A multipoint collection of questions allowed for multiple answers per question. The provincial breakdown (i.e., by percentage) of respondents Poland-wide is presented in Figure 2. A 
brief fiscal summary of the enterprises that partook in the study showed that in 2018, 56.3\% attained net sales of goods, products, services, and financial operations of up to EUR 2 million, $15.9 \%$ attained EUR 2 to 10 million, $12.5 \%$ attained EUR 10 to 50 million, and $15.3 \%$ attained more than EUR 50 million. The case study objectives examined the benefits of the SSC concept, problems related to applying the principles, and SD issues as elements of the policy, strategy, and operational plans of enterprises. The analyses of the study are summarized in terms of percentage.

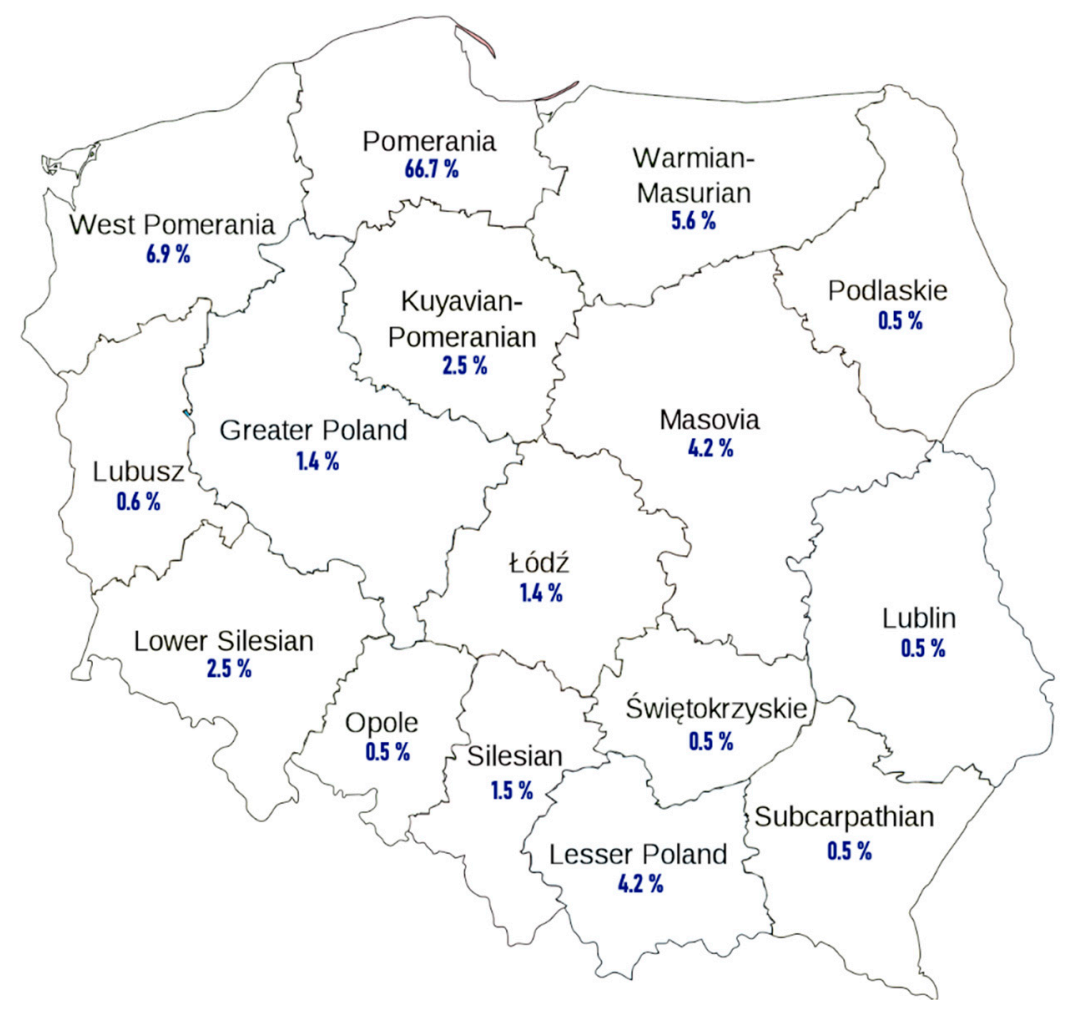

Figure 2. Percentage of participating Polish enterprises broken down by region.

\subsection{Results}

Among the surveyed enterprises, the employee size for SMEs was 80.6\% (i.e., less than 10 employees-36.1\%, 11 to 49 employees-29.2\%, and 50 to 250 employees-15.3\%), while large enterprises employing over 250 people comprised $19.4 \%$. The conducted survey also indicated that $77.8 \%$ of the respondents were familiar with the concept of SSC, of which $26.4 \%$ knew with great detail how it functioned, versus $51.4 \%$ who did not. The remaining respondents, i.e., $22.2 \%$, had never encountered the SSC concept. Overall, these findings affirm a high awareness of SSC and, thus, better support the correlative interplay of the remaining results.

A total of $17.0 \%$ of the respondents stated that the implementation of activities associated with SSC was present within the current enterprise in which they worked. The rest of the respondents, i.e., $83.0 \%$, replied that their current place of employment did not undertake any activities related to the implementation of the concept. In terms of total response frequency, the most mentioned activities in terms of implementation of SSC included: Minimizing the enterprise's negative impact on the local environment, community, and economy (63.9\%), benefiting the local community $(51.4 \%)$, educating suppliers $(40.3 \%)$, and considering the interests of other parties $(36.1 \%)$. These were followed by the respondents taking responsibility for suppliers (34.7\%), respecting legal regulations, standards, and human rights (33.4\%), including representatives of local communities in the decision making $(30.6 \%)$, and honesty towards customers, employees, and business partners (19.4\%). Moreover, the study looked at the benefits (Figure 3) and problems (Figure 4) of SSC when applied within the enterprise for which respondents worked. 
I do not know, it is hard to say

Risk management

Gaining market knowledge

Stability, predictability of business

Care for the natural environment

Financial savings

Good relations with the environment

Positive image

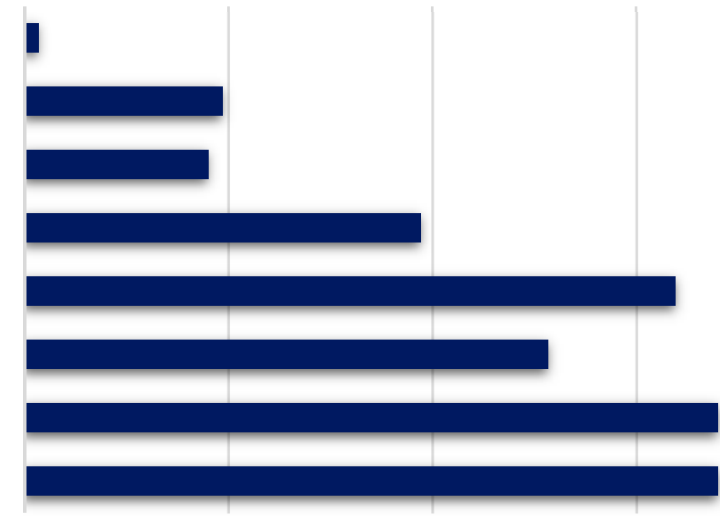

$0 \% \quad 20 \% \quad 40 \%$

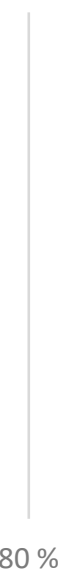

$80 \%$

Figure 3. Benefits of applying the principles of the sustainable supply chain (SSC) within enterprises (i.e., percentage of total response frequency).

$$
\text { I do not know, it is hard to say }
$$

No action by other companies, not the first and only

Lack of involvement of company management

Lack of impact on the regular business activity

Lack of knowledge and skills

Subject complexity

Insufficient time

Required financial outlays

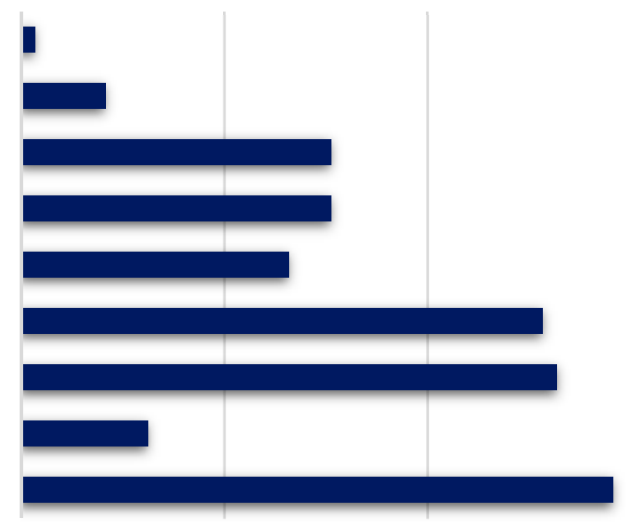

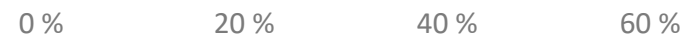

Figure 4. Problems of applying the principles of SSC within enterprises (i.e., percentage of total response frequency).

In response to the application of SSC principles, the last step of the analysis pieced together whether SD subtopics included policy, strategy, and operational plans in the enterprises' composition (Table 2). The results indicate that almost half of the enterprises consider SD issues while developing their missions, objectives, and policies, as well as that over a third have defined strategies for SD implementation. These two subtopics imply a clear effort not only to achieve the enterprise's objective (i.e., to increase profit), but to integrate a high level of strategic thinking and action toward sustainability.

Table 2. SD subtopics as elements of the policy, strategy, and operational plans of enterprises.

\begin{tabular}{cc}
\hline Subtopic & Percentage $^{+}$ \\
\hline The mission, objectives, and policies consider SD issues & 45.8 \\
A defined strategy for SD is implemented & 36.1 \\
Business plans addressing SD are prepared & 29.2 \\
Forms of cooperation with other entities, in order to pursue SD, are implemented & 41.7 \\
Forms of cooperation with other entities, in order to pursue SD, are prepared & 26.4 \\
Cooperation is preferred with other entities that also apply the principles of SD & 20.8 \\
Logistics chains are arranged according to the principles of SSC & 27.8 \\
SD (including SSC) is not included in the strategic elements of the enterprise & 16.7 \\
Other & 2.9 \\
\hline
\end{tabular}

\footnotetext{
${ }^{\dagger}$ Percentage of total response frequency.
} 


\section{Discussion}

The concept of integrated management of SD in the supply chain requires a clear understanding of CSR in business as well as operational development of the SSC. The strategy of an enterprise to develop such rules and procedures requires a willing executive and managerial board (i.e., with knowledge of CSR) as well as an involved dialog with all interest groups. Long-term strategic planning requires strong community support in conjunction with close cooperative arrangements with local leaders and authorities. The ability to integrate and coordinate social issues at all levels needs to be clearly defined in an enterprise's CSR strategy and social role within its entrepreneurial ends. It should be understood that introducing the concept of CSR can be considered an "outside the box" [60,61] view (i.e., to the conventional business model) that takes into account local- and community-centric settings. Smith [62] states that the preparation of an adequate CSR strategy demands that an enterprise identify and understand value by distinguishing overall body from competitors. The integral element between business operations of an enterprise and diversification of strategies at various levels is also elucidated in McWilliams and Siegel [41] and McWilliams et al. [63]. The connection between an enterprise's level of strategy and its social value (i.e., significance) in terms of carrying out CSR and its entrepreneurial operations is illustrated in Figure 5. The pursuit of CSR can unmask future opportunities and threats that remain hidden until a certain level of functionality is achieved (e.g., the development of new products and access to new markets). The pro-social operations of an enterprise on an individual level should focalize on social change and innovation. The utility of entrepreneurialism (i.e., creative spirit) to meet social goals, while still maintaining ethical and moral principles (i.e., within the geographical sphere of the enterprise), is an important part in how future unmasking will play out. Philanthropic action, i.e., on behalf of the enterprise, should be carefully imbedded via entrepreneurial social networking [64] and social behavior of enterprises in relation to value creation (i.e., the process of resource redistribution). The combination and redistribution of resources that create social value (i.e., by stimulating change and fulfilling social need) can expand beyond offering solely new, innovative products and services by expanding outward, by magnifying completely extracurricular entities [65]—including new organizations [66-68].

SSC is the management of TBL impacts as well as the encouragement of good governance practices by way of a well-thought-out products and services lifecycle. Evidently, the objective of SSC is to create, protect, and grow long-term TBL value for all stakeholders involved in bringing products and services to market. There are numerous reasons why enterprises implement SSCs. Primarily, they include compliance with laws and regulations and adherence to and support of international principles and norms for CSR in business. In addition, enterprises are increasingly taking actions that result in better TBL reporting in response to societal expectations and development of business-end benefits. By managing and seeking to improve TBL performance and good governance throughout SSCs, enterprises act in their own interests, interests of their stakeholders, and interests of society at large $[4,69,70]$. By virtue of enterprises' willingness to do business, economic impact is reworked via direct (i.e., payments to employees, suppliers, and governments) and indirect (i.e., monetary flows throughout the supply chain) means. Enterprises which operate their supply chains (more) economically can support further economic development directly (e.g., by way of job creation and higher salaries) and indirectly. Secondary TBL impacts include socioeconomic development as well as environmentally-friendly action and education (i.e., awareness training) [35,60,71]. 


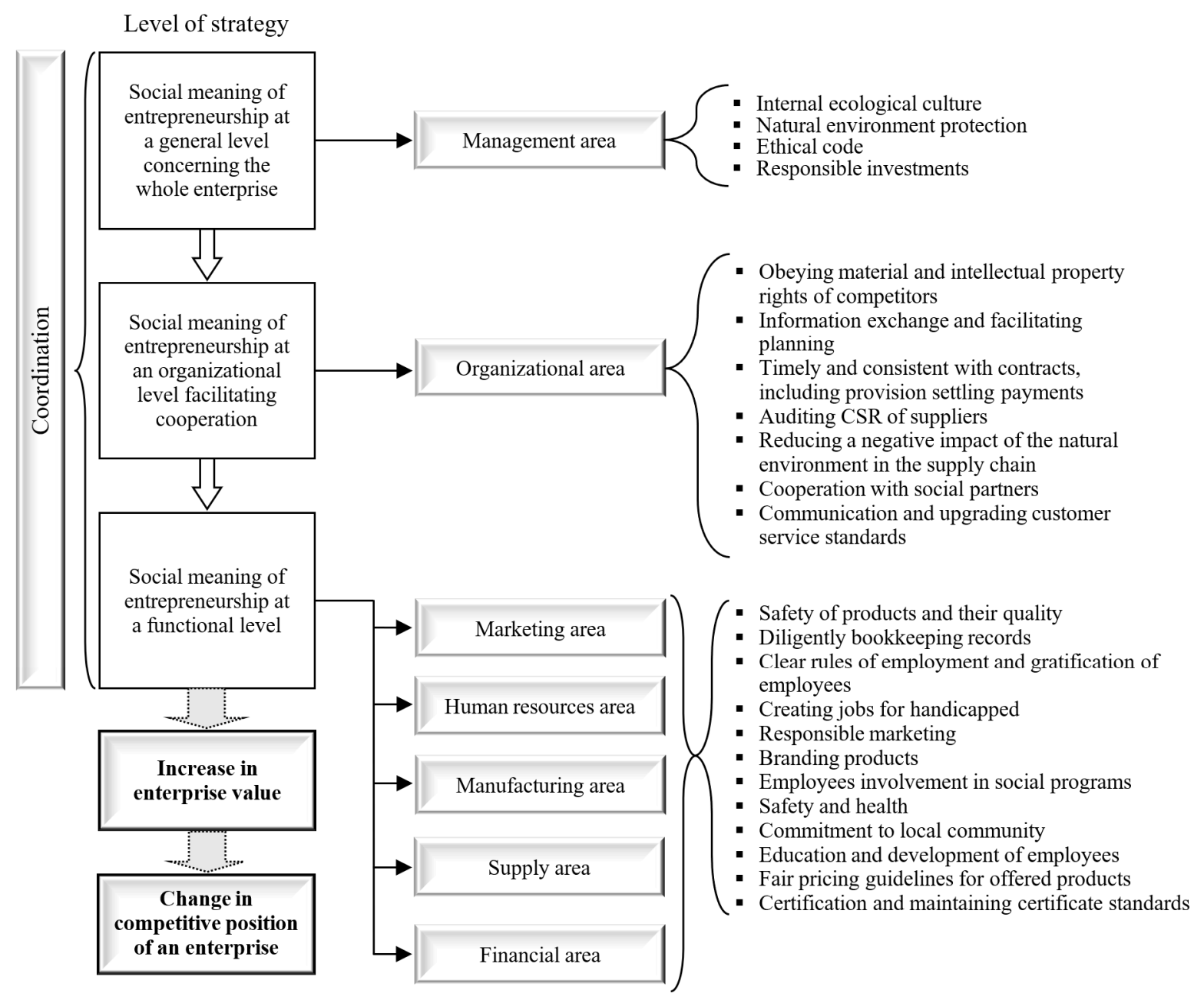

Figure 5. Connection between an enterprise's levels of strategy and its social value in terms of carrying out CSR and entrepreneurial operations.

In terms of the Poland-centric case study, the analyzed similarities between the surveyed enterprises and results from other pro-social enterprise operations-according to Nakonieczna [21]—indicated a number of overlapping trends, including: Enterprise competitiveness, enterprise CSR adjustment (i.e., higher levels of SD sophistication in business, SSC, and value to interest groups), and enterprise-customer loyalty (and vice versa) (i.e., customers associating CSR with the decision to purchase products and services). As a result, it is worth noting that CSR operations require investment in which positive results can favor measurable outcomes [72]. For example, the connection and increase in customer loyalty and reputation of an enterprise-as noted in the total benefits (i.e., frequency) of applying the principles of SSC - noticeably paralleled other positively related studies $[8,31,32,34]$. Similarly, social operations that were found to influence growth of organizational efficiency (i.e., by increasing TBL knowhow) trend toward a positive market share. Social operations were not directly connected with the product production process; as such, facilitated reputation and relational value with external interest groups [73] would need to be enhanced to create enterprise-added value [74]. SSC objectives (i.e., enabling suppliers to meet expectations) align with a wide variety of functions, including supply management professionals, product design, business development, logistics, marketing, and sales. The case study showed that the impact of SSCs brought together cross-functional representatives and bettered enterprise impact and decision making. Important individual roles and responsibilities within the enterprises needed to come from the executive board (i.e., top-down) to best assume CSR for SD implementation, vision, and milestone advancement. 
Objectives backed by incentives and consequences in which SSC personnel provided input to CSR strategic planning enterprise-wide is recommended. To build SD into the decision-making process, sustainability-based expertise should be embedded in, or available to, every business unit impacted by SSCs $[69,70]$. Since the supply chain considers the interactions between an enterprise and its customers and suppliers, the greatest benefits are derived by extending the focus as far possible upstream towards raw materials, downstream towards the consumer, and then back again as the product and waste are recycled. Responsible relations in the supply chain should not be based on imposing rules on suppliers or punishing them for breaching orders if long-term relations have been established. A knowledge of CSR can thus be expanded by regular training as well as knowledge exchange. Cooperation should be utilized in problematic situations-e.g., when standards are violated — to minimize negligence, in order to prevent future reoccurrence.

\section{Conclusions}

Executives of SSCs have a range of possibilities to facilitate SD programs into their enterprises. Redesigning manufacturing plans may lead to an increase in organizational efficiency. As such, as the world's economic advances, technical progress, and negative economic backlash are seen as primary drivers for supply chain efficiency [2,3]. TBL reporting can be used to standardize business value. Appropriately, executives face a series of challenges throughout the SSC to find and maintain SD-compliant practices (e.g., suppliers). Value-making chains increase by way of innovation; as a consequence, they can develop via the maturation of CSR activity directed at improving the environment and societal elements (i.e., in line with a TBL equilibrium). Social investment should be considered a long-term strategic objective, accompanied by investment and focused on improving society. Porter and Kramer [29] affirm that a balanced co-existence, in which both enterprises and society have a reciprocal level of interplay, should be considered healthy. We agree with them and have focused on CSR strategic operations, in compliance with relating interest groups, as vital to doing business $[7,30]$.

The priorities of CSR decision making are referred to as essential structures and processes that should include employee awareness of SD-related matters, a CSR motivation system, and efficient utilization of financial, natural, and human resources [20]. The case study of Polish enterprises broke down the benefits and problems of applying the principles of SSC within enterprises and pieced together SD subtopics as elements of their policy, strategy, and operational plans. The findings found similarities between the surveyed Polish enterprises and results from other pro-social enterprise operations [21] —indicating correlative enterprise competitiveness, the need for CSR fine-tuning, and customer loyalty - as uniform. As such, SSC findings need to be executive and top-down centric for the best supply chain practices $[69,70]$. In terms of the case study, future research could expand the sample size and increase enterprise diversification in and out of Poland. As a national case study, this study falls short, as it did not properly represent the country as a whole, since the majority of the enterprises were all in the region of Pomerania (i.e., 66.7\%). In addition, the extent of the study (i.e., the value analysis of the SSC of enterprises) is at best superficial on the surface, and should be considered as pilot research and representative at this stage. The case study, however, illustrates the benefits and problems of applying SSCs at the enterprise level and reflects many of the problems of applying the principles of SSC via connectivity between levels of strategy and social value in terms of CSR and entrepreneurial operations. Expanding the CSR questionnaire, as well as the collection of data to model a multicriteria analysis and SSC assessment, would be another useful step (i.e., a resourceand time-intensive task outside the purview of this paper). In summary, the underlying concept of SD, i.e., in relation to SSCs, should be to promote not only enterprises and business organizations, but also government, the state, NGOs, academia, and the media alike. Particular focus should be on educational support, in which the scope and role of the media can effectively play a strong, participatory role in motivating entrepreneurs for positive action, cooperation, partnership, and implementation for long-term SD strategies. 
Author Contributions: Conceptualization, A.O.-J.; Data curation, Methodology, Software, Validation, Project administration, Funding acquisition, and Writing-Original Draft preparation, A.O.-J. and E.C.; Investigation, Resources, Visualization, Formal analysis, and Writing-Review and Editing, A.O.-J., E.C., and G.T.C. All authors have read and agreed to the published version of the manuscript.

Funding: This research received no external funding.

Conflicts of Interest: The authors declare no conflict of interest.

\section{References}

1. World Bank Rankings and Ease of Doing Business Score: Economy Rankings. Available online: https: //www.doingbusiness.org/en/rankings (accessed on 30 May 2019).

2. Matopoulos, A.; Barros, A.C.; van der Vorst, J.G.A.J. Resource-efficient supply chains: A research framework, literature review and research agenda. Supply Chain Manag. Int. J. 2015, 20, 218-236. [CrossRef]

3. Reiner, G.; Hofmann, P. Efficiency analysis of supply chain processes. Int. J. Prod. Res. 2006, 44, 5065-5087. [CrossRef]

4. Niranjan, T.T.; Weaver, M. A unifying view of goods and services supply chain management. Serv. Ind. J. 2011, 31, 2391-2410. [CrossRef]

5. Nemtajela, N.; Mbohwa, C. Relationship between Inventory Management and Uncertain Demand for Fast Moving Consumer Goods Organisations. Procedia Manuf. 2017, 8, 699-706. [CrossRef]

6. Jones, D.A.; Willness, C.R.; Glavas, A. When Corporate Social Responsibility (CSR) Meets Organizational Psychology: New Frontiers in Micro-CSR Research, and Fulfilling a Quid Pro Quo through Multilevel Insights. Front. Psychol. 2017, 8, 520. [CrossRef] [PubMed]

7. Boulouta, I.; Pitelis, C.N. Who Needs CSR? The Impact of Corporate Social Responsibility on National Competitiveness. J. Bus. Ethics 2014, 119, 349-364. [CrossRef]

8. Goel, M.; Ramanathan, M.P.E. Business Ethics and Corporate Social Responsibility-Is there a Dividing Line? Procedia Econ. Financ. 2014, 11, 49-59. [CrossRef]

9. Elkington, J. Towards the Sustainable Corporation: Win-Win-Win Business Strategies for Sustainable Development. Calif. Manag. Rev. 1994, 36, 90-100. [CrossRef]

10. Elkington, J. Cannibals With Forks: The Triple Bottom Line of 21st Century Business; New Society Publishers: Stony Creek, CT, USA, 1998; ISBN 1841120847.

11. Elkington, J. 25 Years Ago I Coined the Phrase “Triple Bottom Line." Here's Why It's Time to Rethink It. Harv. Bus. Rev. 2018. Available online: https://hbr.org/2018/06/25-years-ago-i-coined-the-phrase-triplebottom-line-heres-why-im-giving-up-on-it (accessed on 10 July 2019).

12. Kruk, H. Konkurencyjność przedsiębiorstw w świetle zasad rozwoju zrównoważonego. In Przedsiębiorstwo w Otoczeniu Globalnym; Dębicka, O., Oniszczuk-Jastrząbek, A., Gutowski, T., Winiarski, J., Eds.; UG: Gdansk, Poland, 2015; p. 116.

13. Albińska, E. Człowiek w Środowisku Przyrodniczym i Społecznym; Wydawnictwo Katolickiego Uniwersytetu Lubelskiego: Lublin, Poland, 2005.

14. Borys, T.; Śleszyński, J. Ekorozwój jako zbiór zasad. In Wskaźniki Ekorozwoju. Wydawnictwo Ekonomia $i$ Środowisko; Borys, T., Ed.; Foundation of Environmental and Resource Economists: Białystok, Poland, 1999; pp. 85-92.

15. Pigłowski, M. Współczesne uwarunkowanie rozwoju zrównoważonego. In Uwarunkowania Rozwoju Przedsiębiorczości. Determinanty i Narzędzia Zdobywania Przewagi Konkurencyjnej; Adamkiewicz-Drwilło, H.G., Ed.; PWN: Warsaw, Poland, 2007; p. 80.

16. Wąchol, J. Wartość przedsiębiorstwa w aspekcie rozwoju zrównoważonego i trwałego oraz procesów globalizacji. In Zarządzanie Wartością Przedsiębiorstwa a Alokacja Kapitatu; Bielinskiego, J., Ed.; CeDeWu: Warsaw, Poland, 2004; p. 45.

17. Kulig-Moskwa, K. Odpowiedzialność społeczna jako czynnik konkurencyjności przedsiębiorstw w gospodarce opartej na wiedzy. In Europejskie Wymiary Przedsiębiorczości; Kruk, H., Skrzeszewska, K., Eds.; AM: Gdynia, Poland, 2008; p. 137.

18. Chudy, K. Istota konkurencyjności przedsiębiorstw w świetle koncepcji społecznej odpowiedzialności przedsiębiorstw. In Europa Wobec Wyzwań Gospodarki Globalnej; Balcerzak, A.P., Rogalska, E., Eds.; Wyd. Adam Marszałek: Torun, Poland, 2008. 
19. Aguilera, R.V.; Rupp, D.; Williams, C.A.; Ganapathi, J. Putting the S Back in Corporate Social Responsibility: A Multi-level Theory of Social Change in Organizations. Acad. Manag. Rev. 2004, 32, 836-863. [CrossRef]

20. Gasiński, T.; Pijanowski, S. Zarządzanie ryzykiem w procesie zrównoważonego rozwoju biznesu. In Podręcznik dla Dużych i Średnich Przedsiębiorstw; Ministerstwo Gospodarki: Warsaw, Poland, 2011.

21. Nakonieczna, J. Społeczna odpowiedzialność-nowy akcent globalnej strategii przedsiębiorstw międzynarodowych. In Globalizacja a Stosunki Międzynarodowe; Haliżak, E., Kuźniar, R., Simonides, J., Eds.; Wyd. Oficyna Wydawnicza Bratna: Bydgoszcz-Warszawa, Poland, 2004; p. 192.

22. Al-Odeh, M.; Smallwood, J. Sustainable Supply Chain Management: Literature Review, Trends, and Framework. Int. J. Comput. Eng. Manag. 2012, 15, 85-90.

23. Castillo, V.E.; Mollenkopf, D.A.; Bell, J.E.; Bozdogan, H. Supply Chain Integrity: A Key to Sustainable Supply Chain Management. J. Bus. Logist. 2018, 39, 38-56. [CrossRef]

24. Chin, T.A.; Tat, H.H.; Sulaiman, Z. Green Supply Chain Management, Environmental Collaboration and Sustainability Performance. Procedia Cirp 2015, 26, 695-699. [CrossRef]

25. Da Silva, M.E.; Neutzling, D.M.; Alves, A.P.F.; Dias, P.; Dos Santos, C.A.F.; Nascimento, L.F. Sustainable Supply Chain Management: A Literature review on Brazilian publications. J. Oper. Supply Chain Manag. 2015, 8, 29. [CrossRef]

26. Alexander, A.; Walker, H.; Naim, M. Decision theory in sustainable supply chain management: A literature review. Supply Chain Manag. Int. J. 2014, 19, 504-522. [CrossRef]

27. Touboulic, A.; Walker, H. Theories in sustainable supply chain management: A structured literature review. Int. J. Phys. Distrib. Logist. Manag. 2015, 45, 16-42. [CrossRef]

28. Barnett, M.L.; Salomon, R.M. Beyond dichotomy: The curvilinear relationship between social responsibility and financial performance. Strateg. Manag. J. 2006, 27, 1101-1122. [CrossRef]

29. Porter, M.E.; Kramer, M.R. Strategy and Society: The Link between Competitive Advantage and Corporate Social Responsibility. Harv. Bus. Rev. 2006, 84, 78-92.

30. Freeman, R.E.; Harrison, J.S.; Wicks, A.C.; Parmar, B.L.; de Colle, S. Stakeholder Theory: The State of the Art; Cambridge University Press: Cambridge, UK, 2010; ISBN 0521137934.

31. Ministerstwo Gospodarki. CSR: Społeczna odpowiedzialność biznesu w Polsce. In Krajowy Program Reform Europa 2020; Ministerstwo Gospodarki: Warsaw, Poland, 2011.

32. Good Brand CSR w Polsce. Menedżerowie, Menedżerki 500, Lider/Liderka CSR. In Proceedings of the Forum Odpowiedzialnego Biznesu; Good Brand \& Company Polska: Warsaw, Poland, 2010; p. 10.

33. Kärnä, J.; Hansen, E.; Juslin, H. Social responsibility in environmental marketing planning. Eur. J. Mark. 2003, 37, 848-871. [CrossRef]

34. Portal Biznesowy-TP-IR CSR. Available online: http://tp-ir.pl/ (accessed on 31 August 2019).

35. Lu, R.X.A.; Lee, P.K.C.; Cheng, T.C.E. Socially responsible supplier development: Construct development and measurement validation. Int. J. Prod. Econ. 2012, 140, 160-167. [CrossRef]

36. Hillman, A.J.; Keim, G.D. Shareholder value, stakeholder management, and social issues: What's the bottom line? Strateg. Manag. J. 2001, 22, 125-139. [CrossRef]

37. Hafez, H. Corporate social responsibility and firm value: An empirical study of an emerging economy. J. Gov. Regul. 2016, 5, 40-53.

38. Lima Crisóstomo, V.; de Souza Freire, F.; Cortes de Vasconcellos, F. Corporate social responsibility, firm value and financial performance in Brazil. Soc. Responsib. J. 2011, 7, 295-309. [CrossRef]

39. Chen, R.C.Y.; Lee, C.-H. The influence of CSR on firm value: An application of panel smooth transition regression on Taiwan. Appl. Econ. 2017, 49, 3422-3434. [CrossRef]

40. Gompers, P.; Ishii, J.; Metrick, A. Corporate Governance and Equity Prices. Q. J. Econ. 2003, 118, $107-156$. [CrossRef]

41. McWilliams, A.; Siegel, D. Corporate social responsibility and financial performance: Correlation or misspecification? Strateg. Manag. J. 2000, 21, 603-609. [CrossRef]

42. Richardson, A.J.; Welker, M.; Hutchinson, I.R. Managing Capital Market Reactions to Corporate Social Resposibility. Int. J. Manag. Rev. 1999, 1, 17-43. [CrossRef]

43. Cornell, B.; Shapiro, A.C. Corporate Stakeholders and Corporate Finance. Financ. Manag. 1987, 16, 5. [CrossRef]

44. Jamali, D.; Mirshak, R. Corporate Social Responsibility (CSR): Theory and Practice in a Developing Country Context. J. Bus. Ethics 2007, 72, 243-262. [CrossRef] 
45. Mikołajek-Gocejna, M. Wyzwania na szczeblu przedsiębiorstwa-Imperatyw kształtowania wartości. In Przedsiębiorstwo, Wartość, Zarzadzanie; Suszyński, C., Ed.; PWE: Warsaw, Poland, 2007; p. 99.

46. Jo, H.; Harjoto, M.A. Corporate Governance and Firm Value: The Impact of Corporate Social Responsibility. J. Bus. Ethics 2011, 103, 351-383. [CrossRef]

47. Knack, S.; Keefer, P. Does Social Capital Have an Economic Payoff? A Cross-Country Investigation. Q. J. Econ. 1997, 112, 1251-1288. [CrossRef]

48. Goyal, A. Corporate Social Responsibility as a Signalling Device for Foreign Direct Investment. Int. J. Econ. Bus. 2006, 13, 145-163. [CrossRef]

49. Campbell, J.Y. Understanding Risk and Return. J. Polit. Econ. 1996, 104, 298-345. [CrossRef]

50. Brown, W.O.; Helland, E.; Smith, J.K. Corporate philanthropic practices. J. Corp. Financ. 2006, 12, 855-877. [CrossRef]

51. Barnea, A.; Rubin, A. Corporate Social Responsibility as a Conflict Between Shareholders. J. Bus. Ethics 2010, 97, 71-86. [CrossRef]

52. Windsor, D. The future of corporate social responsibility. Int. J. Organ. Anal. 2001, 9, 225-256. [CrossRef]

53. Gasiński, T.; Piekalski, G. Zrównoważony Biznes: Podręcznik dla Małych i Średnich Przedsiębiorstw; Ministerstwo Gospodarki: Warsaw, Poland, 2006.

54. Kim, W.S.; Oh, S. Corporate social responsibility, business groups and financial performance: A study of listed Indian firms. Econ. Res. Istraž. 2019, 32, 1777-1793. [CrossRef]

55. Zuraida, Z.; Houqe, N.; van Zijl, T. Value Relevance of Environmental, Social and Governance Disclosure. In Handbook of Finance and Sustainability; SSRN: Rochester, NY, USA, 2016.

56. Rappaport, A. Ten Ways to Create Shareholder Value. Harv. Bus. Rev. 2006, 84, 66-77.

57. Filek, J. Społeczna odpowiedzialność biznesu. In Tylko Moda Czy Nowy Model Prowadzenia Działalności Gospodarczej? Urząd Ochrony Konsumentów i Konkurentów: Cracow, Poland, 2006.

58. Sjøberg, S.; Schreiner, C. How Do Learners in Different Cultures Related to Science and Technology? Results and Perspectives from the Project Rose. In Asia-Pacific Forum on Science Learning and Teaching; The Education University of Hong Kong: Hong Kong, China, 2005; Volume 6, pp. 1-17.

59. Sullivan, G.M.; Artino, A.R., Jr. Analyzing and interpreting data from likert-type scales. J. Grad. Med. Educ. 2013, 5, 541-542. [CrossRef]

60. Aguinis, H.; Glavas, A. What We Know and Don't Know About Corporate Social Responsibility. J. Manag. 2012, 38, 932-968. [CrossRef]

61. Ararat, M.; Colpan, A.M.; Matten, D. Business Groups and Corporate Responsibility for the Public Good. J. Bus. Ethics 2018, 153, 911-929. [CrossRef]

62. Smith, N.C. Corporate Social Responsibility: Whether or How? Calif. Manag. Rev. 2003, 45, 52-76. [CrossRef]

63. McWilliams, A.; Siegel, D.S.; Wright, P.M. Corporate Social Responsibility: Strategic Implications. J. Manag. Stud. 2006, 43, 1-18. [CrossRef]

64. Hockerts, K. Entrepreneurial Opportunity in Social Purpose Business Ventures. In Social Entrepreneurship; Mair, J., Robertson, J., Hockerts, K., Eds.; Palgrave Macmillan UK: London, UK, 2006; pp. 142-154.

65. Mair, J.; Martí, I. Social entrepreneurship research: A source of explanation, prediction, and delight. J. World Bus. 2006, 41, 36-44. [CrossRef]

66. Glavas, A. Corporate Social Responsibility and Organizational Psychology: An Integrative Review. Front. Psychol. 2016, 7, 144. [CrossRef]

67. Brieger, S.A.; Anderer, S.; Fröhlich, A.; Bäro, A.; Meynhardt, T. Too Much of a Good Thing? On the Relationship Between CSR and Employee Work Addiction. J. Bus. Ethics 2019, 1-19. [CrossRef]

68. De Ruiter, M.; Schaveling, J.; Ciulla, J.B.; Nijhof, A. Leadership and the Creation of Corporate Social Responsibility: An Introduction to the Special Issue. J. Bus. Ethics 2018, 151, 871-874. [CrossRef]

69. Sisco, C.; Chorn, B.; Pruzan-Jorgensen, P.M. Supply Chain Sustainability: A Practical Guide for Continuous Improvement, 2nd ed.; UN Global Compact Office and Business for Social Responsibility: New York, NY, USA, 2010.

70. Gimenez, C.; Sierra, V.; Rodon, J. Sustainable operations: Their impact on the triple bottom line. Int. J. Prod. Econ. 2012, 140, 149-159. [CrossRef]

71. Brammer, S.; Hoejmose, S.; Millington, A. Managing Sustainable Global Supply Chain: Framework and Best Practices; Network for Business Sustainability: London, ON, Canada, 2011. 
72. Brønn, P.S.; Vrioni, A.B. Corporate social responsibility and cause-related marketing: An overview. Int. J. Advert. 2001, 20, 207-222. [CrossRef]

73. Orlitzky, M.; Schmidt, F.L.; Rynes, S.L. Corporate Social and Financial Performance: A Meta-Analysis. Organ. Stud. 2003, 24, 403-441. [CrossRef]

74. Short, J.C.; Moss, T.W.; Lumpkin, G.T. Research in social entrepreneurship: Past contributions and future opportunities. Strateg. Entrep. J. 2009, 3, 161-194. [CrossRef] 